\title{
Identifying Couse and Drivers of Wetland Degradation in Ethiopia: A Review
}

\author{
Diriba Megersa Soboka ${ }^{1 *} \quad$ Leta Hailu Gemechu ${ }^{2}$ \\ 1.Ambo Agricultural Research Center, Ambo, Ethiopia \\ 2.Jimma Agricultural Research Center, Jimma, Ethiopia
}

\begin{abstract}
Ethiopia is endowed with diverse ecosystems in which diverse flora and fauna as well as microbial resources are found. Ethiopia owns diverse types of wetlands, which deliver vast socio-economic and environmental values. However, this ecosystem is exposed to degradation due to adverse human activities. Therefore, the objective of this review was to assess the major threats and drivers of Wetland degradation and suggested conservation strategies in Ethiopia. The identified major threats are drainage for agriculture; overgrazing; invasion of alien species; degradation of catchment lands; over harvesting of their resources, settlement and urban expansion; population growth, water diversion, destructive tree plantation around the wetlands and pollution. While, policy related issue; institutional arrangement issues; issue of capacity shortage; On-site management problem; Off-site management problem and Ecological issue are driving factors those contribute to the threats to the wetlands. Regarding Wetland conservation strategies, real participatory wetland management, involving whole relevant stakeholders, understanding property right regime and institution are things to be considered in addition to offering alternative income generation for the local communities whose depends on the wetland resources. Furthermore, appropriate policy on conservation and management, rule and regulations needs to be established and the action should be taken to sustain the potential and life span of the existing wetlands.
\end{abstract}

Keywords: Conservation strategies; Wetlands degradation; threats; Ethiopia

DOI: $10.7176 / \mathrm{JEES} / 11-2-01$

Publication date: February $28^{\text {th }} 2021$

\section{Introduction}

Wetlands are defined as a distinctive ecosystem in between aquatic and terrestrial ecosystems or are transitional zone ecosystems between dry land and open water body [1]. The global extent of wetlands is now estimated to have declined between $64-71 \%$ in the 20th century, and wetland losses and degradation continue worldwide. Because of wetland losses and degradation, people are deprived of the ecosystem services that wetlands provide. Adverse changes to wetlands, including coral reefs, are estimated to result in more than US\$ 20 trillion in losses of ecosystem services annually. Although populations of wetland species appear to be increasing Ramsar Sites overall, populations of wetland species in the Ramsar Sites in the tropics are decreasing.

There is a negative trend and wetlands are still being lost or degraded, resulting in negative impacts on biodiversity and other ecosystem services [2]. The International Convention on Wetlands was established during 1971 at Iran, Ramsar, with the mission that, "the conservation and wise use of all wetlands through local, regional and national actions and international cooperation, as a contribution towards achieving sustainable development throughout the world" by holding only 18 representative nations [3]. About 163 nations have joined the Convention as Contracting Parties, and more than 2,060 wetlands around the world, covering over 197 million hectares, have been designated for inclusion in the Ramsar list of Wetlands of International Importance [4]. Today, the Ramsar has 168 numbers of contracting countries and 2,186 number of sites designated for the Ramsar List by the total surface area of 208,674,247 hectares, of which Ethiopia is yet not the member [5].

Ethiopia is endowed with diverse ecosystems in which diverse flora and fauna as well as microbial resources are found. The major ecosystems include: Afro-alpine and sub-afro-alpine, wetland, Montane dry forest and scrub, Montane moist forest, Acacia-Comiphora woodland, Combretum-Terminalia woodland, Lowland humid forest, Aquatic, Montane grassland, and Desert and semi-desert ecosystems [6]. The Ethiopian wetlands consist of swamps/marshes, fresh and brackish lakes, riverine flood plains, swamp forests and human made wetlands, which are distributed almost in all parts of the country. The ecological diversity of Ethiopia, characterized by an altitude range from $4620 \mathrm{~m}$ above sea level to $125 \mathrm{~m}$ below sea level, enables it to have all types of wetlands except marine related ones [7]. Ethiopia owns more than 58 different types of wetlands, which provide enormous socio-economic and environmental values [1]. These wetlands roughly estimated to cover $18,580 \mathrm{~km}^{2}$ (around $2 \%$ ) of the total surface area of the country. Seasonally inundated flood plains occupy the largest share of the wetlands $(47.2 \%)$ followed by freshwater lakes $(30.6 \%)$, swamps and marshes $(12.6 \%)$ and the rest is occupied by the other types of wetlands [8].

Although wetlands in Ethiopia cover only a small area (2\%), they are among the most productive ecosystems, and have huge economic, social, and environmental benefits. Compared to other resources like land, water, livestock, etc., the data and information that we have about wetlands are very sparse and incomplete. Separately, 
beyond the information, the real knowledge of our wetlands with reliable figures and data are very limited. This is because wetlands are often assumed as unused lands. Also, the potential of wetlands sustainable development has not been well understood until recently [9], [10]. These indicate that, the larger the threats to our Wetlands and the less consideration for its conservation and wise use. The aim of this review was to assess the threats and conservation of Wetlands of Ethiopia.

\section{Threats to Ethiopian Wetlands and Their Conservation \\ 2.1. Threats to Ethiopian Wetlands}

Wetlands are often considered as idle land and are thought of as obstacles to human development, associated with nuisances and calamities such as floods, diseases such as malaria and other infestation parasites. This view led to the massive conversion of wetlands into other forms of land use that include drainage and land filling for agriculture and infrastructure development, grazing, pollution from the disposal of waste, water diversion/abstraction and mining. There are also activities taking place in wider catchments that affects wetlands like land degradation, deforestation and soil erosion [11].

\subsubsection{Major threats}

Different scholars have listed those threats in different ways; though, their target is similar. Except those are distant from human residence, most threats to our wetlands are anthropogenic; not geological. These threats can be originated from two factors: - Direct factors: those directly imposed on wetlands and Indirect factors: those factors being a causes for other factors to be going on.

The direct causes are Agricultural land expansion, Drainage of wetlands for Agriculture, Over exploitation of the wetland resource (Soil, water, fish, vegetation and reeds) for $\mathrm{d} / \mathrm{t}$ purposes, Over grazing, Urbanization, Different constructions (Dam and Roads), Pollution from Municipal and industrial wastes [12]. Loss of Ethiopian wetlands is mostly due to alteration to farm land, over exploitation of the wetland resource, unregulated management, activities those seriously affecting the wetlands such as: - diversion of water for agricultural intensification, urbanization, dam construction, pollution and other forms of intervention [12], [13]. Except for a few wetlands located in remote and sparsely populated areas, most wetlands in Ethiopia have been altered by human activities, i.e. most threats to our wetlands are not Geological, rather, most of anthropogenic. Hence, the major threats come from: Drainage for agriculture; Overgrazing; Invasion of alien species; Degradation of catchment lands; Over harvesting of their resources settlement and urban expansion; Population Growth, water diversion, distractive tree plantation around the wetlands and pollution are the major threats.

Threats from draining for agriculture and over grazing: Draining the wetlands for agriculture is deliberate action and political issues in some parts of Ethiopia, for example, from my experience around Jimma and West Wollega, there were a season (1999), the government increased their pressuring of farmers to cultivate wetlands in order to compensate for more drought-induced food shortages [13], that draining wetlands and swamps for crop protection and perceived as development strategies. The woredas` and kebeles` leaders were evaluated by Draining or not Draining wet lands to cultivate what the call in local language "Bone". If not draining and not cultivate winter crop, his/her efficiency evaluation will become low. This example is just to elaborate how we concerned to our wetlands and their wise use. In addition to my experience based on [7] that define the major threats, [14] also shows the threats around Jimma in Boye wetland and [15], explain the situation in West Wolega and Ilu-Ababora which supports the same thing.

Figure 1. Evidence collected on degradation of wetlands:

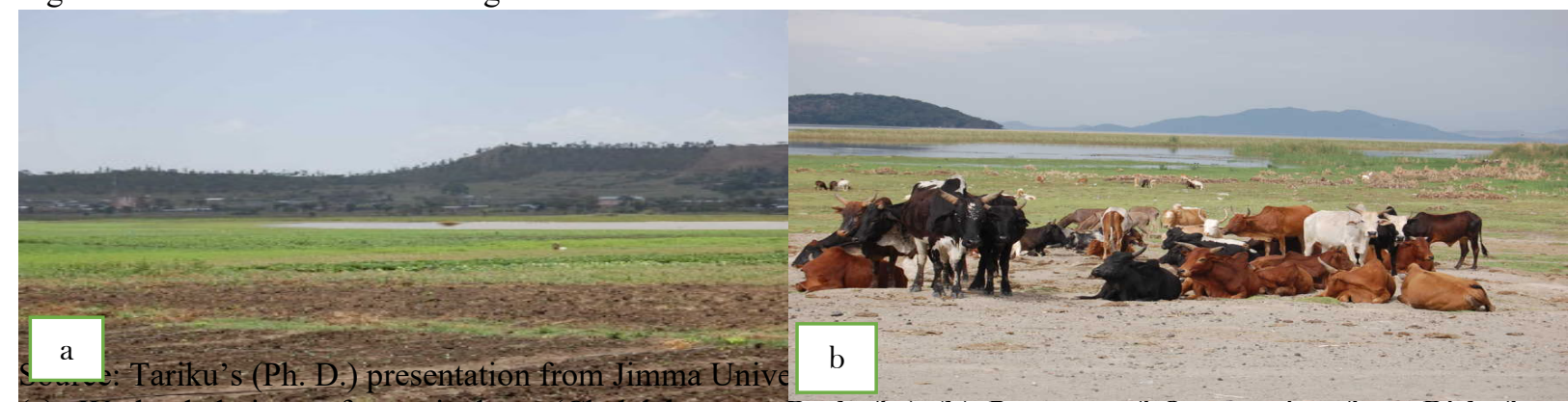

(a) Wetland drainage for agriculture (Cheleleka near Bushoftu) (b) Pressure of Overgrazing from Bishoftu wetland.

Threats from Invasive exotic plant species: Aggressive plant species are another threats to Ethiopian wetlands next to the others. To mention some, invasive alien species, mainly, Parthenium Weed, Mimosa pigra (in Gambella), Prosopis Juliflora (in Afar) and Eichhornia crassipes (in the Rift Valley) are threatening wetlands in Ethiopia. Planting dangerous trees like Eucalyptus species adjacent to the wetlands is also the action that damages wetland ecology. 
Figure 2. Evidence of those harmful invasive plant species on wetlands

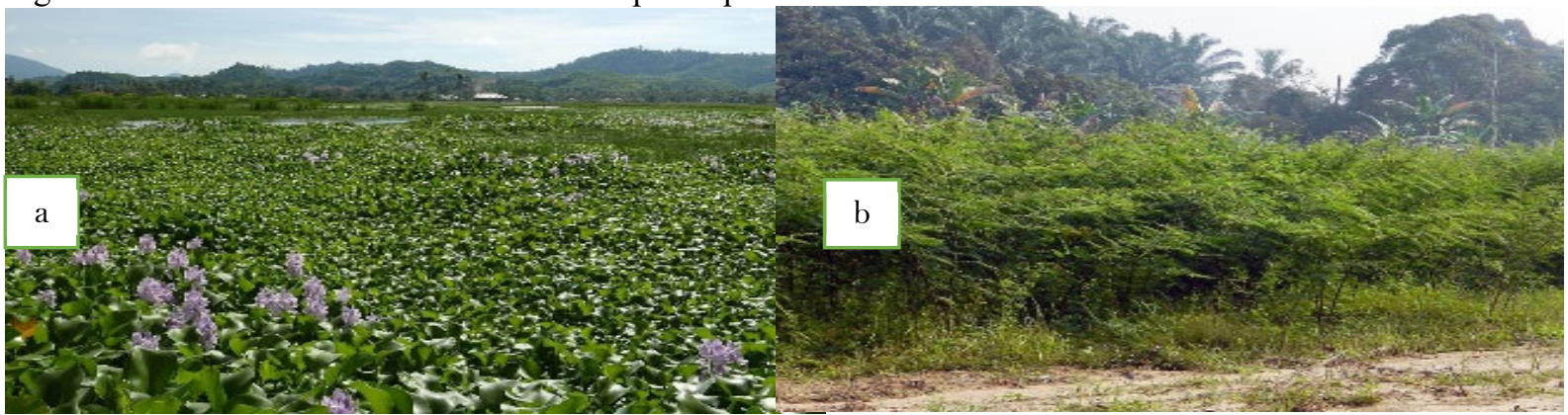

(a) Eichhornia crassipes in the Rift valley- (b) Mimosa pigra- in Gambela Threatening BaroThreatening Koka and Abasamuael reservoirs

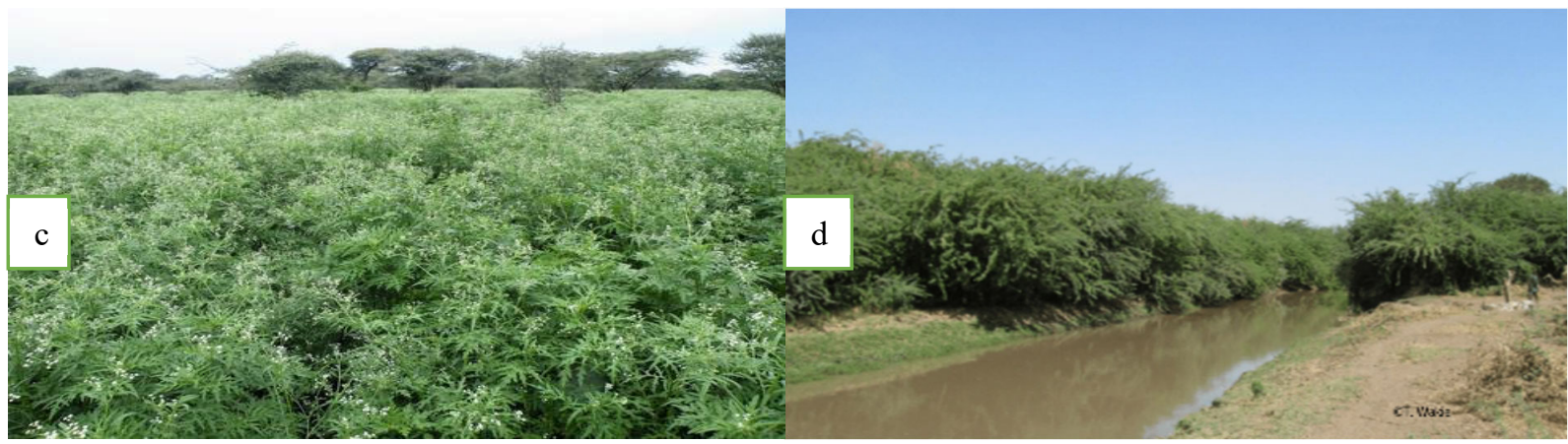

(d) Prosopis Juliflora on wetlands areas of Afar Region, Ethiopia

(c) Parthenium hysterophorus (Asteraceae): The weed that has been threatening both Wetlands and Farm lands in Ethiopia

Source: Photo taken from West Hararge, Machara area during field survey (2017)

lands in Ethiopia

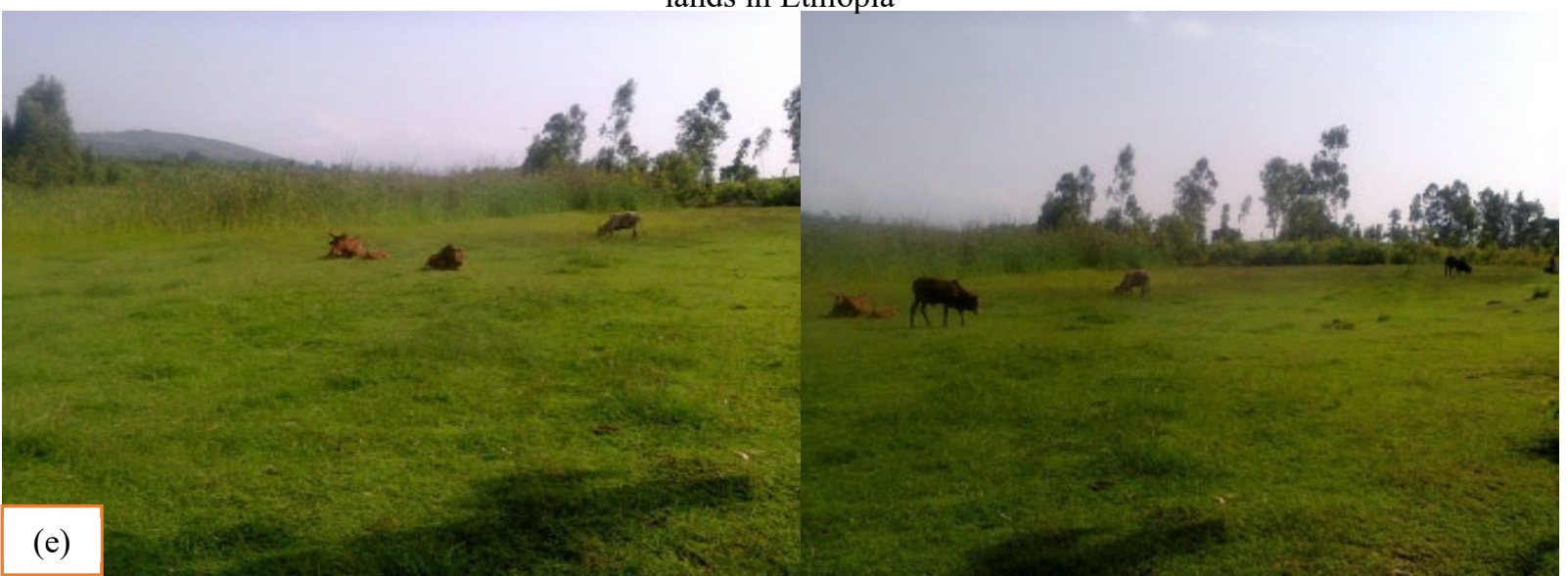

Source: Own photo around Woliso, Ethiopia (2018). (e) Eucalyptus Plantation near wetlands.

Threats from Population Growth and Agricultural expansion: Rapid Population growth is the fundamental cause of the threat generating pressure on wetlands through on-site and off-site interventions. Shortage of lands (cultivation and grazing) resulting from population pressure directly increases encroachment of the wetlands. It also exacerbates the degradation of catchment lands which speed up soil erosion, enhancing siltation in wetlands and thereby imprecise their ecological processes. These problems are serious in densely populated highlands of Ethiopia. For instance, the wetlands on the shores of Lake Tana, which is source of the Blue Nile and some of the rift valley lakes are among the highly threatened from Population pressures [16].

Threats from Pollution (settlement and urban expansion): Towns or Urbans in Ethiopia such as Bahir Dar, Debrezeit, Alemaya, Ziway and Awasa are located adjacent to wetlands or lakes, that, they pose threats from their waste disposal direct discharge into the lakes and swamps [17]. 
Over harvesting of their resources: In addition, wetland resources (e.g. fish and grass-for cattle, sell, shelter roofing and ceremony) are prone to over exploitation; the peripheral lands are reclaimed for infrastructure development and water is pumped out for domestic and agricultural use. In general, the recent total drying up of Lake Alemaya and the precarious existence of Lake Abijata are clear evidence of the looming danger on Ethiopian wetland ecosystem [11], [17], [18].

\subsection{Factors that accelerate wetland losses}

There are driving factors those contribute to the above threats to our wetlands. Among those, some of them are: Policy Related issue; Institutional arrangement issues; Issue of Capacity shortage; On-site management problem; Off-site management problem; Ecological issue

Policy related issues: Lacking of appropriate nation policy on wetland conservation and management, which will protect wetlands from abused utilization is the most important issues. The government has expressed its promise to protect the environment in different policy documents such as the Constitution and Environment policy. However, various competing national priorities such as expansion of agricultural areas to increase food production, resettlement of landless people and investment activities in wetland areas are accelerating wetland loss in different areas.

Strategy documents that favor irrigation agriculture at the expense of wetland ecosystems, including agricultural and water sector forward ideas with harmful implications for the wise use of wetlands. These documents encourage draining and conversion of wetlands into other forms of land use particularly for improving agricultural yield. Wetland issues are also inadequately mentioned in the Water Resource Management Policy (WRMP). The main aim of WRMP is the provision of water for socio-economic development. It does not show the significance of wetlands such as swamps and floodplains in the development of water resources. The Environmental Policy in its general aim of protecting the environment highlights only the importance of wetlands for water resources management [1].

Institutional arrangement issues: As wetlands are source of water, biodiversity and related resources, they attract a number of stakeholders that deal directly or indirectly. There is a need for a coordinator that harmonizes the relationship among the stakeholders and sets better management of wetlands. However, in Ethiopia different stakeholders, local communities, governmental and non-governmental organizations, use wetlands in uncoordinated manner and this approach is affecting the vigor of wetlands and speeding up their degradation. As a result, wise use of wetlands has not yet given proper attention and priority. Different users view wetlands from their own perspective and institutional objective. For instance, agriculturalists see moist fertile soil with vast potential for growing grain; fishery managers find a support base for producing fish; hydrologists calculate capacities to provide water for industry, agriculture, and domestic use; public health specialists may see them as regulators of water quality or in contrary as transmitters of diseases such as malaria; and so on.

Wetland management methodologies practiced so far have their own drawbacks to sufficiently address wetland management problems. For instance, managing wetlands as protected areas did not win the interest of local resource users. Decision makers also do not give warranty to protect wetlands unless they appreciate some definite and critical values in economic terms. As a result, whether they are protected or not, wetlands have become common properties which are overused and as a result degraded. Lack of a comprehensive wetlands policy and implementing law coupled with the absence of an institution duly empowered to issue and implement wetland laws and coordinate management activities is the underlying cause for the deterioration of the wetlands of Ethiopia [1].

Capacity shortage: Capacity shortage is another issue in Wetland management of Ethiopia. It is suffering from capacity limitations such as lack of skilled manpower, finance and technology. Wetland focused training programs are very scarce in higher learning institutions of the country. As a result, there is shortage of wetland specialists. There is also awareness problem from grassroots up to decision maker level. The scarcity of wetland focused institutions and weak relation of the country to wetland affiliated global institutions such as the Ramsar Secretariat has hampered its capacity building opportunities [1].

On-site management problems: When used in sustainable manner wetlands provide numerous services to humans in different forms. Wise use normally diversifies and maximizes benefits that emanate from wetlands. But in contrary to this in most parts of Ethiopia adequate attention is not given to wetland management and wise use. People use recklessly only with the objective of obtaining immediate benefits such as draining for agriculture, overgrazing, excessive resource exploitation, growing destructive plants such as eucalyptus and so on. This is mainly related to rapid population growth, shortage of agricultural land and growing demand for water for investment activities. Conditions that enhance wise use such as community management plans, stakeholder participation mechanisms and awareness or training undertakings in wetland management are not institutionalized and as a result not materialized [1].

Off-site management problems: Wetlands are not isolated entities in the environment. They exist in close interaction with all other ecosystem components in the landscape. Thus they are part of ecosystem process and 
share problems that occur in a watershed in their surroundings. Poor watershed management in the uplands is one of the leading forces that affect wetlands. In most parts of Ethiopia, the catchments that drain into the nearby wetlands have been seriously degraded by human activities that merely focus on exploitation without proper land husbandry. Deforestation, poor farming methods in the uplands and overgrazing by domestic stock are the major factors that degrade watersheds/catchments. Catchment degradation in most cases causes siltation of wetlands. In other instances, catchments are the source of agricultural discharges and pollutants that affect the health of wetland biodiversity. The effluents from domestic use and industrial plants are emerging threats to wetlands adjacent to the major urban and industrial centers of Ethiopia such as Addis Ababa, Mojo, Akaki, Awassa and Bahir Dar [20]. Ecological issues: The incidental and intentional introduction of invasive alien species is another emerging ecological issue severely affecting the wetlands of the country. Some of the world's worst invasive species, which are threatening Ethiopia's wetlands, include Mimosa pigra in the Baro-Akobo

Basin, and Eichhornia crassipes in Koka and Abasamuael reservoirs, prosopis or mesquite (Prosopis juliflora) in Awash River basin, common water hyacinth (Eichhornia crassipes) in Lake Tana and Koka reservoirs, and in Baro-Akobo Basin, M. pigra is aggressively invading wetlands and other areas in the Baro-Akobo Basin, threatening fishing, grazing and other agricultural activities by forming impenetrable thickets and hindering movements of humans and animals, and destroying and replacing natural biodiversity. E crassipes disrupts hydropower generation (e.g. Koka dam), increases siltation and evapotranspiration, reduces fish stocks, impairs water transport and fishing activities, and reduce water quality, thus, the adverse impacts of these invasive species have severe socio-economic and environmental implications [19], [20], [21].

Table 1: Summary of factors, root causes and consequences of the wetland degradations in Ethiopia

\begin{tabular}{|c|c|c|}
\hline Factors & Root Causes & Consequence \\
\hline Policy related issue & $\begin{array}{l}\text { Lack of appropriate national } \\
\text { policy }\end{array}$ & Abused utilization of wetlands \\
\hline Institutional arrangement & $\begin{array}{l}\text { Lack of coordination of } \\
\text { Stakeholders }\end{array}$ & $\begin{array}{l}\text { Degradation } \\
\text { (Irresponsibility) }\end{array} \quad$ of $\quad$ wetlands \\
\hline Capacity shortage & $\begin{array}{l}\text { Lack of skilled manpower, } \\
\text { finance and technology }\end{array}$ & Shortage of wetland specialists \\
\hline On-site management problem & $\begin{array}{l}\text { Lack of wise use of Natural } \\
\text { resource }\end{array}$ & Disrupted wetland service \\
\hline Off-site management problem & $\begin{array}{l}\text { Poor watershed management in } \\
\text { uplands }\end{array}$ & Siltation of wetlands \\
\hline Ecological issue & Invasive species & $\begin{array}{l}\text { Threatening the wetlands and life span } \\
\text { of the dams }\end{array}$ \\
\hline
\end{tabular}

\subsection{Conservation of Ethiopian Wetland}

Most of the conservation status have been discussed in the above, especially, the policy issue (lack of appropriate policy on wetlands conservation) i.e. Country hasn't adopted clearly defined national policy on wetland conservation and management, which leads to on site and off site management problems. These threating the conservation of the existing wetlands. Role of the local institution has the great role in wetland conservation and management. Local knowledge should be acknowledged and local leaders have important role. So that, the local institution is important tools for conservation [15]. As stated in Amsalu and Addisu (2014) [17], for proper conservation, the following issues needed to be considered: -

- Identifying the multi sectoral interest on wetlands, i.e. number of sectors to coordinate their efforts to generate reliable data on the value and other attributes of wetlands to influence policy makers take appropriate actions.

- Incorporating stakeholders in national wetland policy, who play significant role in the design, discussion and implementation of wetland conservation action.

- Protection of wetlands those are in good condition, rehabilitate degraded wetlands where feasible, and support appreciation of wetlands by protecting wetland biodiversity, functions and services through: -

* protecting social and economic benefits of wetlands

* providing flow regimes that mimic natural conditions, where possible

* providing wetlands with water of appropriate volume and quality

- limiting further fragmentation and reconnecting wetland systems through: -

* Preventing or limiting catchment activities that impact upon wetlands;

* Protecting the cultural heritage and spiritual significance of wetlands; 
* Rewarding wetland managers who improve the condition of wetlands; and

* Promoting the Environmental Impact Assessment before undertaking any development that affects wetlands.

- Considerations for technical guide lines: The functions and values of wetlands in the nation; the types of wetlands and resources present in the nation's existing wetlands; historical review of the uses and impacts of development on wetlands; review of existing statistics on inventory and wetland loss; examination of the relationships of wetlands to other sectoral resource management issues; summary of existing legislative and government responsibilities for wetlands; examination of opportunities for program development, partnerships and support; the value of wetlands to the environment and people, with quantified economic values; the review of patterns of use and impacts of development on wetlands. Issue of institutions and property rights associated with resource management decisions should be considered. Realizing the economic values of wetland ecosystems and functions through understanding the property rights regimes, the constraints which they impose on users of wetlands resources, and the distribution of benefits of use among users and non-users.

In Addition to strategies suggested by [11], [17] also suggests some conservation option which possibly related with other`s suggestion. Steps for proper conservation and management: -

Preventing illegal encroachment of the lake for agricultural and other purposes,

Adoption of soil conservation measures and afforestation around the wetland to prevent siltation of the lake. This will help to maintain ecological balance besides preventing sediment deposition. It will also improve the overall productivity of the ecosystem.

Appropriate runoff water harvesting system such as check dams should be adapted by the farmers for application of the water to the crops in the post monsoon season. This will supplement the existing source of irrigation water.

Back flow of irrigation water to the lake should be avoided as the drainage water pollutes the freshwater of the lake due to entry of fertilizers and pesticides which ultimately causes eutrophication and algal growth in the lake.

The establishment of well-organized water users' associations, service and producers' cooperatives will be very useful to develop a well-structured and systematic water management system.

Introduction and popularization of appropriate and improved techniques of irrigation water management such as drip and sprinkler systems should be taken up by the extension service.

Furthermore, [1], also suggests more or less the same thing for conservation strategies as threat reducing opportunities: - impact assessments and continuous monitoring of Wetlands; Building partnerships with stakeholders; Fostering Political Belief (Policy); Prioritization and management plans for wetlands; Monitoring of upstream-downstream user relations. Therefore, for the sustainable utilization of wetland, taking into consideration of the suggested wetland conservation strategies are indispensable.

\section{Conclusion}

The reviewed various research papers and reports are revealed that many of the wetlands are facing loss (degradation) due to direct and indirect threats of human day to day action. Agricultural expansion in Upper watershed causes land degradation which resulting flooding and sedimentation of Wetlands in downstream, converting the Wetlands to crop production and over exploitation of Wetlands` resources (flora, fauna, water and soil), overgrazing, settlement and urban expansion, pollution and water diversion, lack of appropriate national policy on wetland conservation and management, conversion of wetlands to tree plantation site and exotic invasive species are major cumulative threats to Ethiopian wetlands.

Wetland Conservation strategies such as the real Participatory wetland management, involving whole relevant stakeholders, understanding property right regime and institution are things to be considered in addition to facilitating or providing alternative income generation for the local communities whose depends on the wetland resource. Unless the essential management and conservation strategy is in place, the disappearance of more wetlands those escaped and fragile in other part of Ethiopia is unavoidable. To be concerned about the fate of future generation, appropriate policy on conservation and management, rule and regulations needs to be established and the action should be taken, if it needed to sustain the potential and life span of the existing wetlands.

\section{References}

[1] Gebresllassie, H., Gashaw, T. and Mehari, A. Wetland degradation in Ethiopia: causes, Consequences and remedies. Journal of Environment and Earth Science, 4(11), 2014, pp.40-48.

[2] Ramsar Convention Secretariat. The Ramsar Convention briefing note 7, 2015, pp.1-8, found at www.ramsar.org/library.

[3] Ramsar Convention Secretariat, 2011. The Ramsar Convention, Ramsar's Liquid Assets 40 years of the Convention on Wetlands, Gland, Switzerland. 
[4] Ramsar Convention Secretariat. The Ramsar Convention Manual: a guide to the Convention on Wetlands (Ramsar, Iran, 1971), 6th ed. Ramsar Convention Secretariat, Gland, Switzerland, 2013, pp. 6.

[5] Daryade, E., and Talaei, F. Analytical Study on Threats to Wetland Ecosystems and their Solutions in the Framework of the Ramsar Convention and their Solutions in the Framework of the Ramsar, 2014, Pp6-10.

[6] Convention on Biodiversity, CBD. Ethiopia's 4th Country Report, Institute of Biodiversity Conservation Addis Ababa, Ethiopia, November 2009, edited by Dr. Tewolde Berhan G/Egziabher and Mrs. Sue Edwards, 2009, pp10-16.

[7] Abunie, L., 2003. The distribution and status of Ethiopian wetlands: an overview. Wetlands of Ethiopia, 2003, p.12.

[8] EPA (2004): Proceedings of the "National Consultative Workshop on the Ramsar Convention and Ethiopia, the environmental protection Authority in collaboration with the Ramsar Bureau, Addis Ababa, Ethiopia.

[9] Shewaye Deribe (2008). Proceedings of the 'National Stakeholders' Workshop on Creating National Commitment for Wetland Policy and Strategy Development in Ethiopia', Addis Ababa, Ethiopia.

[10] Abebe, Y. D. and Geheb, K. (Eds). Wetlands of Ethiopia. Proceedings of a seminar on the resources and status of Ethiopia's wetlands, 2003, Pp116.

[11] Setegn, Sh., Yohannes, F., Quraishi,Sh. , Chowdary, V. and B.C.Mal,. Impact of Land Use/Land Cover Transformations on Alemaya Lake, Ethiopia, 2009, Pp 4-6.

[12] Bezabih, B. and Mosissa, T. Review on distribution, importance, threats and consequences of wetland degradation in Ethiopia, 2017, Pp6-7.

[13] Mengesha, T. A. Review on the natural conditions and anthropogenic threats of Wetlands in Ethiopian. Global Journal of Ecology, 2(1), 2017, 006-014.

[14] Mekonnen, T. and Aticho, A., (2011), the driving forces of Boye wetland degradation and its bird species composition, Jimma, South western Ethiopia.

[15] Dixon, A, and Wood, A.,2003, Local Institutions for Wetland Management in Ethiopia: Sustainability and State Intervention.

[16] Mequanent, D. and Sisay,A., 2015, Wetlands Potential, Current Situation and Its Threats in Tana Sub-Basin, Ethiopia, Pp12-14.

[17] Amsalu, T., \& Addisu, S. A review of wetland conservation and management policy in Ethiopian. International Journal of Scientific and Research Publications, 4(9), 2014, Pp 656.

[18] Bekele, G. Ms thesis on The Challenges and Opportunities of Wetlands Management in Ethiopia: the case of Abijiata Lake Wetlands, 2009, Pp 40-72.

[19] Dereje A (2003). Fisheries Management: Ecosystem Approach. EPA, In "Tefetro: a Biannual AmharicEnglish, Megazine, Year 2, No.1, and 2003" Addis Ababa, Ethiopia.

[20] Tamene B, Bekele T, Kelbessa E (2000). An Ethnobotanical study of the Semi-Wetland Vegetation of Cheffa. Addis Ababa University, Addis Ababa.

[21] Tikssa M, Bekele T, Kelbessa E. Plant community distribution and variation along the Awash River corridor in the main Ethiopian rift. African Journal of Ecology 48(1):21-28, 2010. 